\title{
Pola Komunikasi di Restoran Capten Nelayan dalam Membangun Motivasi Kerja
}

\author{
Gabriella Amanda Rusli ${ }^{1}$, H.H Daniel Tamburian* \\ ${ }^{1}$ Fakultas Ilmu Komunikasi, Universitas Tarumanagara, Jakarta \\ Email: gabriellaamanda2337@gmail.com \\ ${ }^{2}$ Fakultas Ilmu Komunikasi, Universitas Tarumanagara, Jakarta* \\ Email: danielt@fikom.untar.ac.id
}

Masuk tanggal : 15-12-2021, revisi tanggal : 06-01-2022, diterima untuk diterbitkan tanggal : 06-01-2022

\begin{abstract}
Humans are social beings, meaning that humans need to communicate with others and cannot live without other humans. Humans need interaction with society or organizations in everyday life. Communication is the process of exchanging and receiving messages between communicators and communicants in a language or way that is understood by each other, occurs anywhere, including within organizations, namely organizational communication. Organizational communication patterns are ways that an organization uses to communicate such as send and receive messages. This study aims to determine how the pattern of communication in the Capten Nelayan restaurant and the obstacles faced. The type of research used is qualitative, namely taking data through actual events obtained directly from employees of the organization. Data collection techniques used are with observation, interviews with a number of informants and documentation. The results showed that the communication pattern applied to the Capten Nelayan was a chain pattern, and a circle pattern. The Capten Nelayan Restaurant uses a circular communication pattern when hold meetings so that information can be conveyed evenly and can straighten things that are not clear, and use a chain communication pattern when not in a meeting. The supporting factors are (1) good relations between fellow employees, (2) communication media, (3) commitment. Meanwhile, the factors that inhibit organizational communication patterns are more directed to (1) language (2) inadequate facilitie.
\end{abstract}

Keywords: communication, communication pattern, leader, motivation

\begin{abstract}
Abstrak
Manusia adalah makhluk sosial artinya, manusia butuh berkomunikasi dengan sesama dan tidak dapat hidup tanpa manusia lain. Manusia membutuhkan interaksi dengan masyarakat atau organisasi dalam kehidupan sehari-hari. Komunikasi adalah proses bertukar dan menerima pesan antara komunikator dan komunikan dengan bahasa atau cara yang dimengerti satu sama lain, terjadi dimana saja, termasuk didalam organisasi, yaitu komunikasi organisasi. Pola komunikasi organisasi adalah cara yang diterapkan sebuah organisasi dalam berkomunikasi seperti penyampaian dan penerimaan pesan. Penelitian ini bertujuan untuk mengetahui pola komunikasi di restoran Capten Nelayan dan kendala yang di hadapi. Jenis penelitian yang digunakan adalah kualitatif yakni mengambil data melalui kejadian sesungguhnya yang diperoleh langsung dari anggota organisasi. Teknik pengumpulan data yang digunakan adalah observasi, wawancara terhadap sejumlah informan, dan dokumentasi. Hasil penelitian menunjukkan pola komunikasi yang diterapkan di Capten Nelayan adalah pola rantai, dan pola lingkaran. Restoran Capten Nelayan menggunakan pola komunikasi lingkaran di saat melakukan rapat agar informasi dapat tersampaikan secara merata dan dapat meluruskan hal-hal yang kurang jelas, dan menggunakan pola komunikasi rantai jika tidak sedang rapat. Faktor yang menjadi pendukung ialah (1) Hubungan baik antar sesama anggota, (2) media berkomunikasi, (3)
\end{abstract}


Komitmen. Sedangkan yang menjadi faktor penghambat pola komunikasi organisasi lebih mengarah kepada hal (1) Bahasa (2) fasilitas yang kurang memadai.

Kata Kunci: motivasi, organisasi, pemimpin, pola komunikasi

\section{Pendahuluan}

Manusia adalah makhluk sosial artinya, manusia butuh berkomunikasi dengan sesama dan tidak dapat hidup tanpa manusia lain. Manusia membutuhkan interaksi dengan masyarakat atau organisasi dalam kehidupan sehari-hari. Komunikasi adalah proses bertukar dan menerima pesan antara komunikator dan komunikan dengan bahasa atau cara yang dimengerti satu sama lain. Komunikasi terjadi dimana saja, seperti rumah, sekolah, kampus, hingga organisasi.

Dalam sebuah organisasi, proses komunikasi sangatlah penting untuk mencapai tujuan organisasi. Mereka memiliki cara tersendiri dalam berkomunikasi. Cara berkomunikasi yang dilakukan terus-menerus akan menciptakan sebuah pola. Pola ini dinamakan pola komunikasi, yang secara sederhana dapat diartikan sebagai cara penyampaian informasi dari atasan ke pegawai, maupun antara sesama pegawai. Oktaviana dan Widayatmoko (2018) mengemukakan bahwa komunikasi antara sesama anggota organisasi dapat menimbulkan kesalahpahaman akibat pesan yang tidak tepat, dan organisasi dapat berjalan kurang baik. Sementara itu Harlim dan Sukendro (2019) menyatakan, komunikasi dalam sebuah organisasi pasti lebih terorganisir dan memiliki aturan untuk menciptakan proses komunikasi baik.

Penulis menyadari bahwa pola komunikasi yang diterapkan dalam sebuah organisasi pasti sangat memengaruhi ketepatan informasi yang diterima seluruh anggota organisasi. Pola komunikasi yang baik dan terarah pasti dapat membangun motivasi kerja anggotanya.

Sunyoto (2012) mengungkapkan bahwa membangun motivasi di tempat bekerja memiliki tujuan, yakni (1) membuat karyawan menjadi bersemangat dan bergairah, (2) menambah moral dan kepuasan kerja, (3) menambah tingkat produktivitas karyawan, (4) mempertahankan kestablian dan loyalitas, (5) menambah kedisiplinan serta mengurangi absensi karyawan, (6) mengadakan hubungan kerja yang baik, (7) menambah kreativitas karyawan, (8) menambah tingkat kesejahteraan, (9) membuat karyawan memiliki rasa tanggung jawab, dan (10) membuat pengadaan karyawan menjadi efektif.

Omollo (2015), mengartikan motivasi kerja adalah sesuatu yang menyebabkan individu memiliki dorongan semangat dalam bekerja. Selain Omollo, Jatmiko (2015) juga mengungkapkan bahwa motivasi kerja adalah sesuatu yang dapat menggerakkan individu atau kelompok secara terarah untuk mencapai tujuan tertentu.

Berdasarkan latar belakang di atas, maka rumusan masalah dari penelitian ini adalah bagaimana pola komunikasi antara pimpinan dan bawahan di restoran Capten Nelayan dalam membangun motivasi kerja. Capten Nelayan adalah perusahaan yang menjual makanan hasil laut yang dibekukan. Capten Nelayan adalah perusahaan yang bergerak di bidang kuliner, didirikan pada tahun 2012 yang berlokasi di Kedoya, Jakarta Barat.

Penulis ingin menggambarkan pola komunikasi organisasi pemimpin Capten Nelayan ke dalam karya ilmiah yang akan dikerjakan dengan metode kualitatif, dengan judul "Pola Komunikasi Organisasi Antara Pimpinan dan Bawahan Restoran 
capten nelayan dalam Membangun Motivasi Kerja”. Penelitian ini dilakukan untuk: (1) mengetahui pola komunikasi antara pimpinan dan bawahan di restoran Capten Nelayan dalam membangun motivasi kerja; (2) mengetahui kendala-kendala dalam berkomunikasi untuk membangun motivasi kerja; (3) mengetahui faktor pendukung yang membangun motivasi kerja karyawan; (4) mengetahui apakah ada satu pola komunikasi yang cocok dalam membangun motivasi kerja.

\section{Metode Penelitian}

Pendekatan Penelitian ini adalah kualitatif dengan cara deskripsi dan analisa. Aktivitas yang dideskripsikan adalah komunikasi yang terjadi di organisasi antara pemimpin dann pegawai. Dalam penelitian, sebuah metode adalah aspek yang sangat penting untuk mengumpulkan data. Metode merupakan sebuah cara untuk mencari data, mengumpulkan data, baik secara primer dan sekunder. Data yang didapatkan kemudian akan di analisa untuk menguji penelitian. Data yang diperoleh penelitian ini berasal dari realita sesungguhnya dari objek yang diteliti.

Metode deskriptif adalah metode yang digunakan untuk menggambarkan atau menganalisis suatu hasil penelitian tetapi tidak digunakan untuk membuat kesimpulan yang lebih luas (Sugiyono, 2011). Pendekatan deskriptif kualitatif digunakan sebagai metode dengan memanfaatkan data kualitatif kemudian dideskripsikan untuk menganalisis suatu peristiwa atau keadaan secara sosial (Moleong, 2017). Metode penelitian yang dipakai dalam penelitian ini adalah deskriptif kualitatif. Metode deskriptif kualitatif adalah suatu pendekatan yang menggambarkan keadaan suatu status fenomena yang terjadi dengan kata-kata atau kalimat. Penelitian ini dilakukan dengan metode deskriptif kualitatif karena penulis akan mendeskripsikan data sesuai dengan informasi dari sumber dan menganalisa dengan teori yang ada.

Penulis akan melakukan trianggulasi dengan cara observasi, wawancara, dan dokumentasi.

1. Obervasi.

Menurut Sugiyono (2015) Observasi adalah teknik pengumpulan data mempunyai ciri yang spesifik bila dibandingkan dengan teknik yang lain, yaitu wawancara. Obervasi tidak terlepas dari sumber wawancara namun, dalam obervasi penulis akan ikut serta bersama informan untuk melihat kenyataan yang ada di lingkungan penelitian, dan meneliti objek sekitar seperti suasana.

2. Wawancara.

Menurut Sugiyono (2015) Wawancara adalah teknik pengumpulan data apabila peneliti ingin melakukan studi pendahuluan untuk menemukan permasalahan yang harus diteliti, tetapi juga apabila peneliti ingin mengetahui hal-hal dari responden yang lebih mendalam. Wawancara akan dilakukan secara tatap muka, dengan informan yang terpercaya, dan sudah bekerja di perusahaan selama 3 tahun.

3. Dokumentasi.

Dokumentasi yang akan penulis dokumentasikan adalah foto suasana kerja dan fasilitas perusahaan sebagai dokumen pendukung penelitian ini.

Data akan diolah secara kualitatif, sehingga menghasilkan kesimpulan berupa penalaran. Pengolahan data akan dilakukan dengan 3 cara. yaitu:

1. Reduksi data. 
Data yang didapatkan penulis akan di reduksi atau dirangkum menjadi suatu kesatuan, sehingga memudahkan penulis dalam menganalisa. Reduksi dimulai dari awal penulis mengumpulkan data, hingga selesai mengumpulkan data.

2. Penyajian data.

Penyajian data secara kualitatif berupa uraian kata-kata yang akan disusun secara sistematis dan logis agar mudah dipahami pembaca, meliputi gambar.

3. Penarikan kesimpulan.

Penarikan kesimpulan harus dapat dipertanggung jawabkan, maka uraian kesimpulan harus dijabarkan berdasarkan data yang ada, dan ditulis secara logis agar kesimpulan dari penelitian dapat dimengerti oleh pembaca.

\section{Hasil Temuan dan Diskusi}

\section{Penerapan Pola Komunikasi di Restoran}

Dalam penyampaian komunikasi di restoran Capten Nelayan, pola komunikasi yang diterapkan adalah pola lingkaran dan pola rantai. Pola lingkaran digunakan pada saat rapat mingguan maupun rapat besar. Pola komunikasi lingkaran diterapkan saat rapat agar pembagian informasi merata, misalnya mengenai omset penjualan atau rancangan strategi tahunan.

Selain dari rapat, komunikasi yang diterapkan di restoran Capten Nelayan adalah pola rantai. Hal ini dapat disimpulkan karena dalam penyampaian informasi dari direktur utama, tidak langsung disampaikan kepada karyawan. Informasi dari direktur akan disampaikan kepada manajer dan jajarannya, setelah diolah menjadi lebih matang, informasi tersebut akan disampaikan dari manajer kepada masingmasing bawahannya. Begitupun sebaliknya, jika bawahan mengalami kendala atau keluhan dalam bekerja, karyawan tidak diperkenankan untuk langsung menghadap direktur dan menyampaikan masalahnya.

Penerapan pola rantai yang diterapkan di Capten Nelayan dapat membangun motivasi kerja pegawai karena memberi kepuasan kerja bagi pegawai. Sebuah organisasi pasti menerapkan pola komunikasi tertentu dalam organisasinya untuk mencapai tujuan. Restoran Capten Nelayan menerapkan pola komunikasi untuk meminimalisir terjadinya kesalahpahaman pembagian tugas.

\section{Arus Komunikasi dari Atas ke Bawah}

Penerapan arus komunikasi dari atas kebawah yang biasanya terjadi di restoran Capten Nelayan tidak harus selalu mengenai pekerjaan. Biasanya dalam setahun akan diadakan kegiatan di luar kantor seperti perkemahan, wisata ke luar kota, yang berlangsung beberapa hari untuk menjalin komunikasi yang baik dengan sesama anggota restoran. Komunikasi yang terjadi saat kegiatan di luar restoran dapat terjadi arus dari bawah ke atas, namun tetap memperhatikan etika dan menghormati pemimpin.

\section{Arus Komunikasi dari Bawah ke Atas}

Komunikasi dari bawah ke atas biasanya berupa diskusi pekerjaan, meminta saran jika pegawai mengalami kesulitan dalam mengerjakan tugasnya, atau memberi ide dan masukan terhadap rencana yang digunakan untuk mencapai tujuan restoran. 
Komunikasi berupa kritik terhadap restoran juga bisa disampaikan, jika mendesak bisa disampaikan kepada manajer agar dapat diterima oleh direktur, namun jika bukan kritik yang mendesak, dapat disampaikan pada saat rapat tahunan restoran.

Berdasarkan penelitian yang penulis lakukan, arus komunikasi di restoran Capten Nelayan mengikuti struktur organisasi secara teratur. Komunikasi arus ke bawah cocok diterapkan saat atasan memberi arahan, instruksi, dan perintah. Komunikasi arus ke bawah juga dapat berupa pemaparan tujuan restoran, visi misi restoran, peraturan restoran baik yang sudah pernah diterapkan maupun peraturan baru. Sedangkan komunikasi arus ke atas cocok diterapkan saat pegawai memberi ide, saran, pendapat, dan kritikan kepada pemimpin.

Di restoran Capten Nelayan, pola komunikasi yang diterapkan adalah pola rantai dan pola lingkaran. Pola komunikasi rantai memiliki arus dari atas ke bawah, dan dari bawah ke atas, namun arus komunikasi yang lebih banyak terjadi adalah dari atas ke bawah, yaitu dari pemimpin ke pegawai. Komunikasi dari pemimpin ke pegawai berupa arahan, perintah, instruksi seperti yang disampaikan manajer keuangan.

Direktur restoran Capten Nelayan sangat terbuka kepada pegawainya, sehingga permasalahan yang muncul dalam pekerjaan dapat teratasi dengan cepat karena banyaknya sumber saran yang direktur terima. Pola komunikasi ini terlihat membangun motivasi kerja, karena pendapat yang diterima oleh atasan membuat pegawai merasa dihargai.

\section{Arus Komunikasi ke Samping}

Komunikasi juga terjadi ke samping, atau ke sesama jajaran seperti jajaran manajer dapat saling berdiskusi mengenai rencana pembagian tugas, atau strategi penjualan berikutnya agar dapat bersama-sama mencapai tujuan restoran. Komunikasi sesama jajaran akan terasa lebih nyaman seperti manajer dengan sesama manajer, staff dengan sesama staff.

Penyampaian pesan berantai memang memiliki kelebihan dan kekurangan. Kelebihannya pesan yang melalui perantara dapat mendapatkan ide tambahan, sedangkan kekurangannya adalah adanya kemungkinan pesan berubah makna ketika disampaikan ke orang terakhir.

Penerapan pola rantai di restoran capten nelayan terlihat membuahkan hasil, gabungan ide dan inovasi dari staff dan manajer menghasilkan sebuah karya yang membanggakan. Dalam hal ini, kebutuhan seorang manusia dalam segi aktualisasi diri dan penghargaan, telah tercapai.

Komunikasi dalam kehidupan manusia adalah hal utama yang sangat penting. Dalam sebuah organisasi, komunikasi yang baik sangat dibutuhkan untuk menunjang profesionalitas kerja. Hal-hal yang menunjang komunikasi yang baik antara pemimpin dan pegawai, ataupun pegawai dengan sesamanya pastinya akan memberi kepuasan dalam bekerja.

Adanya umpan balik dari restoran terhadap kinerja pegawai, menjadi pemacu pegawai lebih termotivasi lagi dalam bekerja, umpan balik dalam ungkapan akuntan diatas adalah berupa tunjangan, bonus, dan fasilitas. Selain pola komunikasi yang tepat, pemberian penghargaan berupa materi terhadap hasil kerja pegawai adalah hal yang sangat penting karena pegawai mencapai kepuasan kerja, dan semakin semangat lagi dalam bekerja karena kebutuhan materinya juga tercukupi.

Jika terdapat banyak faktor pendukung dalam pola komunikasi yang diterapkan di restoran Capten Nelayan, maka pastinya ada faktor-faktor yang 
menjadi hambatan atau dikatakan sebagai kendala dalam penerapan pola komunikasi di restoran Capten Nelayan antara pemimpin dan bawahan dalam membangun motivasi kerja pegawainya.

Berikut adalah hambatan yang dialami restoran Capten Nelayan yaitu, hambatan komunikasi. Hambatan komunikasi ini berupa kesalahpahaman. Karena adanya perbedaan isi pesan dari pegawai kepada direktur. Pegawai yang memiliki atasan lagi sebelum sampai kepada direktur harus memberikan ide atau menyampaikan saran melalui atasannya, lalu atasannya akan menyampaikan kepada direktur. Pada tahap penyampaian informasi dari atasan ke direktur, terjadi kesalahpahaman atau ketidaktepatan penyampaian informasi. Berdasarkan pola komunikasi rantai, orang terakhir yang menerima pesan biasanya mendapat pesan yang kurang lengkap atau kurang tepat.

\section{Simpulan}

Restoran Capten Nelayan menerapkan pola komunikasi lingkaran dan pola komunikasi rantai sebagai cara berkomunikasi dalam restoran. Pola komunikasi lingkaran dilakukan ketika rapat, sehingga pembagian informasi merata ke seluruh bagian. Restoran Capten Nelayan memiliki struktur organisasi yang harus dipatuhi dan dihormati. Strukturnya berupa direktur lalu turun ke manajer, lalu turun ke staff seperti administrasi, juru masak, dan pelayan. Pola komunikasi rantai yang diterapkan di restoran Capten Nelayan dapat penulis simpulkan membangun motivasi kerja. Komunikasi dari atas kebawah berupa instruksi dapat diterima bawahan denganbaik, komunikasi dari bawah ke atas berupa kritik dan saran juga diterima dengan sangat baik, begitu pula dengan komunikasi kesamping, seperti kepada sesama rekan kerja setingkat. Atasan yang disiplin namun mengayomi bawahannya dengan sangat baik, begitu pula dengan bawahan yang menghormati atasannya.

Kendala yang dihadapi anggota restoran Capten Nelayan dalam berkomunikasi sehingga berpengaruh kepada motivasi kerja adalah hambatan bahasa. Adanya atasan restoran Capten Nelayan yang berbahasa asing membuat terjadinya sedikit kesalahpahaman karena bahasa yang digunakan kurang dipahami pegawai namun perlahan dapat diatasi dengan baik. Lalu, masalah sinyal wifi restoran yang kurang bagus sehingga terkadang sulit untuk berkomunikasi dengan atasan atau bawahan yang sedang bekerja dari rumah. Faktor pendukung yang membangun motivasi kerja pegawai adalah rasa nyaman berkomunikasi dengan atasan yang selalu menanggapi ide, saran, kritik, dan memberi solusi, mengayomi bawahannya.

\section{Ucapan Terima Kasih}

Peneliti ingin mengucapkan terima kasih kepada Fakultas Ilmu Komunikasi Universitas Tarumanagara, narasumber, serta semua pihak yang turut membantu peneliti sehingga penelitian ini dapat diselesaikan.

\section{Daftar Pustaka}

Harlim, C \& Sukendro, G.G (2019). Proses Komunikasi Organisasi di dalam Biro Iklan di Ada Indonesia dan Ada Singapura, Koneksi, Vol. 3, No. 2, Desember 2019, Hal 501-505. 
Jatmiko, E., Swasto, B., N, G. (2015). Pengaruh Motivasi Kerja dan Komitmen Organisasional terhadap Kinerja Karyawan (Studi pada Karyawan Kompartemen Pabrik II PT. Petrokimia Gresik). Jurnal Administrasi Bisnis (JAB), 21(1).

Moleong, L. J. (2017). Metodologi penelitian kualitatif(Revisi). Penerbit Rosda.

Omollo, P. (2015). Effect of motivation on employee performance of commercial banks in Kenya: A case study of Kenya Commercial Bank in Migori County. International Journal of Human Resource Studies, 5(2), 87-10.

Oktaviana, S \& Widayatmoko (2018). Jaringan Komunikasi Antara Pimpinan dan Karyawan dalam Menumbuhkan Komitmen Karyawan di PT. Digital Suplai Indonesia, Koneksi, Vol. 2, No. 2, Desember 2018, Hal 556-561.

Sugiyono (2011). Metode Penelitian Kuantitatif, Kualitatif dan R\&D. Bandung: Afabeta.

Sugiyono (2015). Metode Penelitian Kombinasi (Mix Methods). Bandung: Alfabeta. 